The effect of inference-making, deduction, and self-monitoring on EFL learners' language achievement, reading, and writing ability

\title{
Bagheri, Fahimeh
}

Imam Reza International University, Mashhad, Iran (fbagheri2010@yahoo.com)

Ghanizadeh, Afsaneh $\bowtie$

Imam Reza International University, Mashhad, Iran (ghanizadeafsane@yahoo.com; a.ghanizadeh@imamreza.ac.ir)

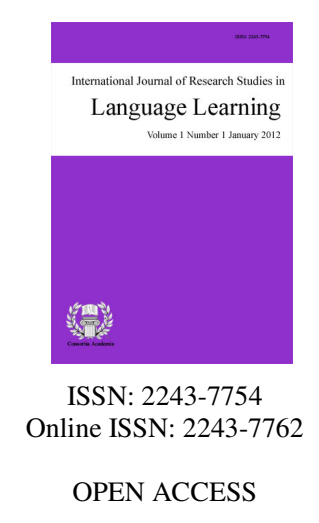

\section{Abstract}

In line with the studies demonstrating the positive relationship between critical thinking ability, self-regulation and language proficiency, this study aimed to particularly examine the impact of the two subcomponents of critical thinking, i.e., inference-making and deduction, as well as one subcomponent of self-regulation, i.e., self-monitoring, on EFL students' overall language achievement, reading and writing achievements. To the best of researchers' knowledge, there is no documented study investigating the relationship between these constructs among EFL learners. To achieve the purpose of the study, 120 EFL university students were selected according to a convenience sampling from Hakim Sabzevari University, a city in the north-east of Iran. They were asked to complete the "Watson-Glaser's Critical Thinking Appraisal" and the "Self-Regulation Trait Questionnaire". They were also requested to report the grade point average of their previous term together with their reading and writing scores on these courses. The results showed that there is a significant relationship between EFL learners' inference-making, deduction, self-monitoring and their language achievement as well as their reading and writing ability. Subsequent data analyses demonstrated that among the variables, self-monitoring is the most powerful predictor of language achievement. In addition, the results revealed that the three mentioned variables can predict about 27 percent of language achievement. This study has some implications for educators and administrators to take full advantage of these associations by establishing guiding principles for enhancing EFL university students' self-monitoring, inference-making, and deduction.

Keywords: inference-making; deduction; EFL learners; self-monitoring; language achievement; reading comprehension; writing ability 


\section{The effect of inference-making, deduction, and self-monitoring on EFL learners' language achievement, reading, and writing ability}

\section{Introduction}

American Philosophical Association Project offered the definition of critical thinking as "purposeful, self-regulatory judgment which results in interpretation, analysis, evaluation and inference and is founded on the conceptual criteria upon which a judgment is based" (Facione \& Facione, 1996). Theoretically and pedagogically, critical thinking is currently a subject of prime interest among many scholars and most researchers have strongly endorsed the integration of critical thinking into other areas of foreign language acquisition (Bailin, Case, Coombs, \& Daniels, 1999). Scholars advocating critical thinking skills have convincingly contented that enhancing thinking skills must be urgency for educationalists. There is now a considerable empirical and theoretical base in the literature to confirm the connection of critical thinking with students' academic achievement (e.g. Lee \& Loughran, 2000; Keeley, Holland, \& Watson, 2005). It is reasonably believed that higher-order thinking skills can improve higher order learning skills contributing to academic success (Renner, 1996).

Another variable studied in this paper is self-regulation. It refers to "self-generated thoughts, feelings, and actions that are planned and cyclically adapted to the attainment of personal goals" (Zimmerman, 2000, p. 14). Zimmerman (1990) asserted that self-regulated learners are meta-cognitively, motivationally, and behaviorally active participants in their own learning process. Self-regulatory skills have been confirmed to bear close relations to academic achievement and motivation to accomplish educational goals (Zimmerman \& Schunk, 2001). Moreover, as the findings of previous studies (Graham \& Harris, 1993; Zimmerman \& Risemberg, 1997; Monshi Toussi, Bori, \& Ghanizadeh, 2011; Ghanizadeh \& Mirzaee, 2012) indicated, self-regulation is considered as an influential strategy in foreign language learning and teaching.

The major purpose of this study is to empirically investigate the theorized association between self-monitoring, a component of self-regulation, and inference-making and deduction, two components of critical thinking, as well as language achievement among EFL learners. The researchers of the present study aimed to explore this connection according to logical reasoning as well as theoretical frameworks in the literature indicating a close association between critical thinking ability and self-regulatory skills (Phan, 2010). To the best of researchers' knowledge, there is hardly any documented study investigating the association between the components of critical thinking and self-regulation. In this study, the researcher investigated the hypothesized associations among university students majoring in EFL.

\section{Review of the Related Literature on Critical Thinking}

According to different researchers and theorists in the field of critical thinking, there is a broad range of definitions proposed for it. For instance, Paul (1995) introduced CT as set of intellectual standards that individuals can use while thinking. Pithers and Soden (2000) defined critical thinking as a cognitive ability mingled with numerous skills such as identifying, understanding and analyzing a matter by drawing inferences using top-down and bottom-up strategies to confirm the reliability of claims and rationales. The term can also be defined as the use of analytical skills, attitudes and values to get close to the truth to a great extent (Gabennesch, 2006). Furthermore, Norris and Ennis (1989) believed critical thinking is "reasonable and reflective thinking that is focused upon deciding what to believe and do" (p. 3).

Examining these definitions, one can find considerable overlap between them. In fact, all these definitions convey the same message and are paraphrases of the same concepts. They simply relate critical thinking to reasoning and rational judgments (Davidson, 1998). Although most scholars agree that critical thinking is a 
combination of both skills and dispositions, skill-based models and measures of critical thinking are widely-used categorizing it as a higher-order thinking skill and pivoting on conceiving proper learning and instructions processes (Frijters, Dam, \& Rijlaarsdam, 2008). For example, Watson and Glaser (2002), the designers of the widely-known measure of critical thinking, related it to the following abilities: differentiating among degrees of truth or falsity of inferences; identifying underlying assumptions in a group of sentences; determining if conclusions are credible or not; recognizing whether conclusions follow from the information given in a sentence, and assessing arguments as being strong or weak, i.e. being relevant or irrelevant.

Moon (2008) believed that critical thinking and its relationship with the educational process has developed into a major issue, so it is appropriate to fully explore it. She also mentioned since critical thinking is a process involved in any research activity; it can be regarded as a predominant concept in education, especially at higher levels. In fact, it is the primary aim of learning. In a similar vein, Davidson (1998) asserts that higher order thinking skills, especially critical thinking, should be an indispensable part of L2 learning to improve language proficiency of students (as cited in Liaw, 2007). Critical thinking is presumed to be significant in the acquisition of language skills, in particular reading and writing (Seung-Ryul Shin, 2002; Stapleton, 2001; Moore, 1995).

Throughout the history, Paul (2004) has attempted to relate critical thinking to reading comprehension. According to him, as the reflective mind enhances its power by thinking about it reflectively, it also enhances its reading by thinking deeply about how it is reading. Facione (1992), moreover, believed there is a high correlation between critical thinking ability and reading comprehension. In fact, enhancement in one is paralleled by enhancement in other. Considering reading comprehension as a crucial factor in second language learning and teaching, Barnett (1989) explained a number of reasons for its importance: It continues to be a principal aim in many programs; it encourages the development of literacy skills; and it continues to be after students finish formal language study. Inference, synthesis, analysis and evaluation are among some of the mental skills used in reading comprehension (Grabe, 1991). According to Facione (1992), these skills lie at the heart of critical thinking.

Researchers underline the importance of writing skill in the progress of learners. As Pecorari (2006) asserted that the ability to write appropriate text is an important part of academic success. A number of methods and approaches to language teaching are aimed at writing skill to show its essence and its intricacies. For example, Whole Language proponents endorse the idea that not only is writing employed as a way of displaying knowledge to a teacher but also as a means of discovering for a person what he thinks (Rigg, 1991). Moreover, Brown (2001) stated that writing skill and thinking are closely related and inseparable from each other; therefore, the more ability one possesses to think, the better that person is going to handle writing.

\section{Review of the Related Literature on Self-regulation}

Self-regulation refers to the "process of setting goals for oneself and engaging in behaviors and cognitive processes that lead to goal completion" (Ormrod, 2006, p. 347). Considering academic self-regulation, Zimmerman (2000) described it as how much learners are motivationally, metacognitively, and behaviorally active in their learning process and in accomplishing their goals (as cited in Ghanizadeh \& Ghonsooly, 2014). Consequently, from this we can reasonably infer that successful students actively participate in their own learning procedure. In fact, as Wolters, Pintrich, and Karabenick (2003) pointed out motivation, management, monitoring, behavior, and the like are among the main components of self-regulation.

According to Heikkilä and Lonka (2006), self-regulated learners are more apt to set task-related, rational goals, assume responsibility for their learning, and preserve motivation. Furthermore, students who are regulated in their learning are competent at employing and changing wide-ranging cognitive (e.g., memorizing, practicing, organizing) and metacognitive (e.g., setting goals, monitoring, planning, self-evaluation) strategies to succeed in performing academic tasks.

Many recent studies have revealed that self-regulation and academic achievement are closely related. Ee, 
Bagheri, F., \& Ghanizadeh, A.

Moore, and Atputhasamy's (2003) study, for instance, illustrated that learners with higher achievements have better attributes to consider and apply self-regulatory strategies which go hand in hand with their achievement. Likewise, Zimmerman and Martinez-Pons's (1986) research showed self-regulated learning strategies such as environmental structuring; looking for information, reviewing text, and setting goals enhance the students' achievement. It has also been proven that self-regulatory strategies facilitate crucial independent learning areas, e.g., reading and writing (Zimmerman \& Kitsantas, 1999).

Research on the field of self-regulation indicated that self-regulation can facilitate reading ability in particular (McMahon \& Dunbar, 2003; Nash-Ditzel, 2010; Swalander \& Taube, 2007). Harris and Hodges (1995) added that unless students are self-monitoring while reading, they cannot fully understand the text. Self-monitoring is associated with the concept of "metacognitive awareness," known as the ability to know whether what one is reading is truly understood by monitoring and controlling one's own comprehension (Harris \& Hodges, 1995, p. 153). To write and read effectively, students need to develop self-regulation skills (Graham \& Harris, 2000; Hayes \& Flower, 1980; Zimmerman \& Kitsantas, 1999). Among the different self-regulation skills, self-monitoring is claimed to be of great significance in learning to write and read (Cresswell, 2000; Xing, 2004). Self-monitoring in writing and reading involves assessing and recognizing some compatibility or incompatibility of what has been written with a mental representation of what the text is expected to be (Hacker, 1994).

\subsection{Purpose of the Study}

The main purpose of the present study is to empirically investigate the hypothesized associations between $\mathrm{CT}$, in particular inference and deduction, and self-regulation, in particular self-monitoring, with EFL university students' academic achievement in reading and writing and also their overall language achievement. To achieve this purpose, the following research questions were posed and probed in the present study:

$>\quad$ Is there any relationship between EFL university students' self-monitoring, language achievement as well as reading and writing achievement?

$>\quad$ Is there any relationship between EFL university students' inference-making, language achievement as well as reading and writing achievement?

$>\quad$ Is there any relationship between EFL university students' deduction, language achievement as well as reading and writing achievement?

$>\quad$ What percentage of variability in EFL university students' language achievement can be accounted for by their self-monitoring, inference-making, and deduction skills?

\section{Method}

\subsection{Participants}

The participants of the present study comprised 120 EFL university learners studying English Literature at Hakim Sabzevari University. Out of 120 participants, 97 students were female and 23 were male. After a brief explanation of the purpose of the research, all participants received the Watson-Glaser's Critical Thinking Appraisal and also Self-Regulation Trait (SRT) Questionnaire. To gather reliable data, the purpose of completing the questionnaire was explained and the participants were assured that their views would be confidential.

\subsection{Instruments}

The Farsi Version of the Watson-Glaser's Critical Thinking Appraisal (CTA) - To evaluate students' inference-making and deduction, two subtests of Watson-Glaser Critical Thinking Appraisal (CTA) were employed. During the history of CT researches, various general tests of CT have been utilized by several researchers. For the purpose of the present study, WGCTA was used because it has widely been employed by CT researchers (e.g. Ghanizadeh, \& Moafian, 2011). In the present study, the Persian version of the Watson-Glaser test was employed. According to Mohammadyari (2002), this test and its subcomponents are truly reliable and valid according to Iranian culture. To ascertain the reliability of the questionnaire, she employed split-half 
Effect of inference-making, deduction, \& self-monitoring on language achievement, reading, \& writing ability

reliability estimate. Moreover, with the adapted version in Iran, the reliability was discovered to be 0.98 and the results of the factor analysis provided some support for the inventory hypothesized structure (Mohammadyari, 2002).

\section{Table 1}

The Subtests of CTA Used in this Research along with the Corresponding Descriptions

\begin{tabular}{cc} 
Subtest & Description \\
\hline Test 1. Inference & Discriminating among degrees of truth or falsity of inference drawn from given data.
\end{tabular}

Test 2. Deduction

Determining whether certain conclusions necessarily follow from information in given statement or premises.

Self-Regulation Trait (SRT) Questionnaire - To measure self-monitoring, the self-regulation trait (SRT) questionnaire designed by O'Neil and Herl (1998) was applied. This subtest consists of 8 questions ranging from almost never, to sometimes, often, and almost always. The following table depicts the subscale of the SRT used in this research.

Table 2

The Subscale of SRT Used in this Research together with the Corresponding Descriptions

\begin{tabular}{clc}
\hline \multicolumn{1}{c}{ Factor } & \multicolumn{1}{c}{ Definition } & \multicolumn{1}{c}{ Items } \\
\hline Self-monitoring & The extent to which one needs a & 2-6-10-14-18-22-26-30 \\
& $\begin{array}{l}\text { self-checking mechanism to } \\
\text { monitor goal achievement }\end{array}$ & \\
\hline
\end{tabular}

The reliability and validity of the scale have been confirmed in many studies (Herl et al., 1999).

\subsection{Data Collection}

The study was conducted at Hakim Sabzevari university of Sabzevar, a city in the north east of Iran. The participants were required to complete the self-monitoring scale of the Self-Regulation Trait questionnaire and the inference and deduction scales of the Watson-Glaser Critical Thinking Appraisal. The questionnaires were arranged numerically and they were asked not to write their names. No one took the test home, or left the class while taking the test. They were also asked to report the grade point average (GPA) of their previous term and their reading and writing scores. Since the participants were already briefed on the purpose of the study and given that all participants were guaranteed anonymity and confidentiality, it was hoped that these would add the validity to the students' report of their academic scores.

\subsection{Data Analysis}

To check the normality of data distribution, the Kolmogorov-Smirnov test was employed. To investigate the relationship between self-monitoring, language achievement, reading and writing achievement, multiple Pearson Product-Moment correlations were applied to the data. To examine the relationship between inference-making, language achievement, reading and writing achievement, multiple Pearson Product-Moment correlations were run. To explore the relationship between deduction, language achievement, reading and writing achievement, multiple Pearson Product-Moment correlations were run. To explore what percent of variability in EFL learners' language achievement can be accounted for by their scores in the variables under study, a multiple regression analysis was conducted.

\section{Results}

To check the normality of data distribution, the Kolmogorov-Smirnov test was employed. This test is used to check whether the distribution deviates from a comparable normal distribution. If the $p$-value is non-significant 
Bagheri, F., \& Ghanizadeh, A.

$(p>.05)$, we can say that the distribution of a sample is not significantly different from a normal distribution, therefore it is normal. It the $p$-value is significant $(p<.05)$ it implies that the distribution is not normal. Table 3 presents the results of the Kolmogorov-Smirnov test. As it can be seen, the obtained sig value for all variables (self-monitoring, inference-making, and deduction) is higher than .05. Therefore, it can safely be concluded that the data is normally distributed across all four variables.

Table 3

The Results of K-S Test for Self-monitoring, Inference-making, and Deduction

\begin{tabular}{lccc}
\hline & \multicolumn{3}{c}{ Kolmogorov-Smirnov } \\
\cline { 2 - 4 } & Statistic & df & Sig. \\
\hline Self-monitoring & .076 & 120 & .088 \\
Inference-making & .092 & 120 & .061 \\
Deduction & .096 & 120 & $.052^{*}$ \\
\hline
\end{tabular}

The same analysis was conducted for GPA, reading, and writing scores. Table 4 presents the results. As it can be seen, all these variables are normally distributed across the participants.

Table 4

The Results of K-S Test for GPA, Reading, and Writing Scores

\begin{tabular}{lccc}
\hline & \multicolumn{3}{c}{ Kolmogorov-Smirnov } \\
\cline { 2 - 4 } & Statistic & df & Sig. \\
\hline GPA & .981 & 120 & .094 \\
Writing & .978 & 120 & .051 \\
Reading & .942 & 120 & .055 \\
\hline
\end{tabular}

Table 5 presents descriptive statistics of EFL learners' self-monitoring, inference-making, and deduction. The results are as follows: self-monitoring $(M=22.60, S D=3.35)$, inference-making $(M=6.10, S D=2.53)$, and deduction $(M=9.53, S D=2.12)$.

\section{Table 5}

Descriptive Statistics of Self-monitoring, Inference-making, and Deduction

\begin{tabular}{lccccc}
\hline & $\mathrm{N}$ & Minimum & Maximum & Mean & Std. Deviation \\
\hline Self-monitoring & 120 & 12.00 & 30.00 & 22.60 & 3.53 \\
Inference-making & 120 & 2.00 & 14.00 & 6.11 & 2.53 \\
Deduction & 120 & 4.00 & 14.00 & 9.53 & 2.13 \\
Valid N (listwise) & 120 & & & & \\
\hline
\end{tabular}

Table 6 presents descriptive statistics of EFL learners' GPA, writing and reading scores. The results are as follows: self-monitoring $(M=22.60, S D=3.35)$, inference-making $(M=6.10, S D=2.53)$, and deduction $(M=9.53$, $S D=2.12$ ).

Table 6

Descriptive Statistics of GPA, Reading, and Writing Scores

\begin{tabular}{lccccc}
\hline & $\mathrm{N}$ & Minimum & Maximum & Mean & Std. Deviation \\
\hline GPA & 120 & 12.50 & 19.00 & 16.00 & 1.45 \\
Writing & 120 & 10.00 & 20.00 & 15.44 & 2.16 \\
Reading & 120 & 11.00 & 20.00 & 16.80 & 1.84 \\
Valid N (listwise) & 120 & & & & \\
\hline
\end{tabular}


Effect of inference-making, deduction, \& self-monitoring on language achievement, reading, \& writing ability

5.1 The relationship between self-monitoring, language achievement, reading and writing achievement

To investigate the relationship between self-monitoring, language achievement, reading and writing achievement, multiple Pearson Product-Moment correlations were applied to the data. Table 7 indicates the results.

Table 7

The Correlation Coefficients between Self-monitoring, GPA, Reading and Writing Achievement

\begin{tabular}{lc}
\hline & Self-monitoring \\
\hline GPA & $.520 * *$ \\
Writing & $.449 * *$ \\
Reading & $.329 * *$ \\
\hline Note. ${ }^{* *}$ Correlation is significant at the level of 0.05 &
\end{tabular}

According to Table 7, there is a significant correlation between self-monitoring and GPA $(r=0.520, p<$ $0.05)$, self-monitoring and writing $(r=0.449, p<0.05)$, and self-monitoring and reading $(r=0.329, p<0.05)$.

5.2 The relationship between inference-making, language achievement, reading and writing achievement

To examine the relationship between inference-making, language achievement, reading and writing achievement, multiple Pearson Product-Moment correlations were run. Table 8 indicates the results.

\section{Table 8}

The Correlation Coefficients between Inference-making, GPA, Reading and Writing Achievement

\begin{tabular}{lc}
\hline & Inference-making \\
\hline GPA & $.310^{* *}$ \\
Writing & $.440^{* *}$ \\
Reading & $.410^{* *}$ \\
\hline
\end{tabular}

Note. $* *$ Correlation is significant at the level of 0.05

According to Table 8, there is a significant correlation between inference-making and GPA $(r=0.310, p<$ $0.05)$, inference-making and writing $(r=0.440, p<0.05)$, and inference-making and reading $(r=0.410, p<$ $0.05)$.

5.3 The relationship between deduction, language achievement, reading and writing achievement

Identical analysis was performed for deduction. To explore the relationship between deduction, language achievement, reading and writing achievement, multiple Pearson Product-Moment correlations were run. Table 9 indicates the results.

Table 9

The Correlation Coefficients between Deduction, GPA, Reading and Writing Achievement

\begin{tabular}{lc}
\hline & Deduction \\
\hline GPA & $.252^{* *}$ \\
Writing & $.449 * *$ \\
Reading & $.419 * *$ \\
\hline
\end{tabular}

Note. $* *$ Correlation is significant at the level of 0.05

According to Table 9, there is a significant correlation between deduction and GPA $(r=0.252, p<0.05)$, deduction and writing $(r=0.449, p<0.05)$, and deduction and reading $(r=0.419, p<0.05)$.

5.4 The role of self-monitoring, inference-making, and deduction in predicting language achievement

To explore what percent of variability in EFL learners' language achievement can be accounted for by their 
Bagheri, F., \& Ghanizadeh, A.

scores in variables under study, a multiple regression analysis was conducted. The following Table is the ANOVA table of regression for self-monitoring, inference-making, and deduction in predicting language achievement. In this analysis, GPA is dependent variable and self-monitoring, inference-making, and deduction are considered as independent variables. The magnitude of $F$-value $(F=15.796)$ and the amount of the respective $p$-value $(p<0.05)$ indicate the considered model is significant.

\section{Table 10}

The ANOVA Table of Regression for the Variables under Study

\begin{tabular}{llccccc}
\hline & Model & Sum of Squares & df & Mean Square & F & Sig. \\
\hline \multirow{2}{*}{1} & Regression & 72.083 & 3 & 24.028 & 15.796 & $.000^{\mathrm{b}}$ \\
Residual & 176.449 & 116 & 1.521 & & \\
\multicolumn{2}{l}{ Note. a. Dependent Variable: GPA, b. Predictors: (Constant), Deduction, Self-monitoring, Inference-making } &
\end{tabular}

As Table 11 shows, all the three variables are positive predictors of the dependent variable, i.e., language achievement. This can be figured out by examining the magnitude of the $t$-value (which should be higher than the critical level) and the $p$-value (which should be less than the significance level, i.e., 0.05). It was also found that among the variables, self-monitoring is the most powerful predictor of language achievement.

\section{Table 11}

The Results of Regression Analysis for the Variables under Study

\begin{tabular}{llccccc}
\hline \multirow{2}{*}{ Model } & \multicolumn{2}{c}{ Unstandardized Coefficients } & $\begin{array}{c}\text { Standardized } \\
\text { Coefficients }\end{array}$ & $\mathrm{t}$ & Sig. \\
\cline { 2 - 7 } & \multicolumn{1}{c}{$\mathrm{B}$} & Std. Error & Beta & & \\
\hline \multirow{2}{*}{1} & 11.039 & .783 & & 14.105 & .000 \\
& (Constant) & .188 & .035 & .460 & 5.328 & .000 \\
& Self-monitoring & .075 & .050 & .182 & 2.005 & .045 \\
& Inference-making & .057 & .059 & .099 & 1.950 & .050 \\
\hline
\end{tabular}

Note. a. Dependent Variable: GPA

Table 12 illustrates the model summary statistics. The results revealed that the model containing the three variables (self-monitoring, inference-making, and deduction) can predict about 27 percent of language achievement. The $\mathrm{R}$ value is 0.539 which indicates the correlation coefficient between the variables. Its square value is 0.290 and its adjusted square is 0.272 . It indicates that about 27 of the variation in language achievement can be explained by taking the above-mentioned variables into account.

\section{Table 12}

$R$ Square Table for Self-Monitoring, Inference-Making, and Deduction in GPA

\begin{tabular}{ccccc}
\hline Model & $\mathrm{R}$ & $\mathrm{R}$ Square & Adjusted R Square & Std. Error of the Estimate \\
\hline 1 & $.539^{\mathrm{a}}$ & .290 & .272 & 1.23333 \\
\hline Note. a. Predictors: (Constant), Deduction, Self-monitoring, Inference-making
\end{tabular}

\section{Discussion}

The primary concern of this study was to examine whether there is a relationship between Iranian EFL students' CT ability, in particular inference-making and deduction, and their self-regulation, in particular self-monitoring, as well as reading and writing achievement. Furthermore, this study tried to uncover to what extent the above-mentioned variables could predict students' language achievement. Considering our first research question which asked whether there is a relationship between EFL university students' self-monitoring, language achievement, reading and writing achievement, the result of the present study revealed that there was a significant relationship between these variables. This finding suggests that students exhibiting a higher level of 
self-monitoring can logically have better achievements in reading, writing and language achievement. In other words, it can be concluded that teaching self-monitoring techniques can significantly promote reading and writing performance in college students, and it develops students' independent skills. This is hardly surprising since, as demonstrated earlier in this study, multiple studies revealed that self-regulated individuals were, on the whole, higher achievers and more motivated to accomplish academic goals compared with other learners with less self-regulatory skills (e.g., Zimmerman \& Schunk, 2001; Ee et al., 2003; Schunk \& Pajares, 2001; Monshi Toussi, Boori, \& Ghanizadeh, 2011; Ghanizadeh \& Mirzaee, 2012). Since self-monitoring is a subscale of self-regulation, this contention can reasonably be generalized to this sub-factor as well.

In the same line with this study, Pratontep and Chinvonno (2008) aimed to investigate learners' self-regulated learning strategies in an Extensive Reading program. Results suggested that there were major differences between learners' reading mean scores after 10 weeks of instruction in self-regulated strategies. Nash-Ditzel (2010) also reported that teaching techniques based on self-regulation and reading strategies can significantly enhance reading abilities in college students. Moreover, this study empirically showed that students with strong gains in self-monitoring also showed strong gains in writing quality which is consistent with self-regulated learning theories (Hayes \& Flower, 1980; Winne \& Hadwin, 1998). This result is also in line with Graham and Harris's self-regulated strategy development (SRSD) model, asserting that self-regulated writing positively affects writing performance (Graham \& Harris, 1993).

The researchers' second question aimed at investigating the relationship between EFL university students' inference-making, language achievement, reading and writing achievement. The results demonstrated a significant relationship between the variables in question, which is also in line with the previous theoretical and empirical contentions related to critical thinking. For instance, studies indicating the relation between critical thinking skills, as measured by the California Critical Thinking Skills Test (CCTST; Facione et al., 1990), and GPA have shown correlations ranging between .235 and .596 (Facione \& Facione, 1997). Ghanizadeh and Mirzaee (2012) confirmed that EFL learners' critical thinking can predict about $28 \%$ of their language achievement. Throughout history, a range of other studies have demonstrated the association of critical thinking with students' academic success as well (e.g., Lee \& Loughran, 2000; Kealey, Holland, \& Watson, 2005).

The correlation of critical thinking to reading comprehension indicates that individuals who benefit from a higher level of critical thinking should logically perform better on reading section of exams. This was not far behind the expectation of the researchers of the present study. Accepting the definition of reading comprehension by Dorothy Durkin (1993), "intentional thinking during which meaning is constructed through interactions between text and reader", and also the clarification of this construction of meaning as "a complex merger of skills, prior knowledge and text mediated by the language skills, motivation and interest of the reader" (Block, Gambrell, \& Pressley, 2002), one can reasonably infer that it covers Bloom's taxonomy in critical thinking including "knowledge, comprehension, application, analysis, synthesis, and evaluation" (Bloom et al., 1956). Since critical thinking and comprehension both are cognitive abilities having some common cognitive skills, improvement in one can contribute to the improvement of the latter- reading comprehension.

The findings of the present study are also consistent with empirical studies. Nasirahmadi (2014) concluded in his study that critical thinking can predict $38 \%$ of the learners' success in IELTS reading section. Fahim and Kamali's (2011) research also demonstrated that there is a positive correlation between learners' critical thinking ability and their reading comprehension. Moreover, Miller (1981) showed students' achievement in critical thinking was closely associated with their reading proficiency achievement.

In a similar vein, some practitioners of reading, among them Harvey and Goudvis (2000), Tovani (2000) and Beers (2003), have stressed the paramount importance of teaching reading strategies to improve reading comprehension, but one of the essential reading strategies is inferencing. Being competent in drawing inferences is crucial in the comprehension of text (Caine \& Oakhill 1999). Similarly, less skilled readers make fewer inferences than their skilled counterparts (e.g. Long, Oppy, \& Seely 1997; Oakhill 1982, 1984). 
With regard to the relationship between critical thinking and students' writing achievement, we can argue that the results of our study support previous research. For instance, Jodeiri (2005) demonstrated the association between critical thinking and writing proficiency of Iranian EFL students. Eventually, he discovered that there is a close relationship between the critical ability and English writing skill of Iranian intermediate EFL learners. The better performers in critical thinking ability they are, the more sophisticated their English writing skill would be. As students begin to write, they encounter a plethora of opportunities to struggle with their thoughts, hence promoting their cognitive and intellectual growth(Bean \& Weimer, 2011). More specifically, Quitadamo and Kurtz (2007) in their study demonstrated that writing helps students enhance their inference skills. Writing is effective because students must not only organize their thoughts conceptually but also monitor their awareness of thinking processes (Langer \& Applebee, 1987; Ackerman, 1993; Holliday, 1994; Rivard, 1994).

Leafing through the existing literature on critical thinking, one can reasonably infer that there is a close association between critical thinking and students' reading and writing achievement. Since inference-making and deduction are two subcomponents of critical thinking, we can reasonably infer that each of them play a part in influencing critical thinking ability. On the other hand, this study is unique in its own in that it exclusively investigated the correlation of the two subcomponents of critical thinking with reading and writing skills, while to the researchers' best knowledge there is hardly any documented study with the same purpose. Thus, the researchers of the present study approached the third question in the same way as the second one, and everything mentioned regarding the relationship between critical thinking and reading and writing skills can also be applied to the third question. The findings of this study indicated a moderate correlation between deduction and reading and writing skill.

The researchers' fourth question aimed at finding the role of self-monitoring, inference-making, and deduction in predicting language achievement. The results revealed that 27 percent of the variation in language achievement can be explained by taking the mentioned variables into account. This is consistent with the previous studies suggesting that gains in critical thinking as well as the ability to self-regulate one's learning are correlated with higher levels of achievement (Harter, 1996; Markman, 1979; Schunk, 2005; Zimmerman, 2000). It was also found that among the variables, self-monitoring is the most powerful predictor of language achievement. Regarding the central importance of self-monitoring, many studies have argued that it is one of the characteristics of good learners and promotes learning (Blanche \& Merino, 1989; O’Malley \& Chamot, 1990; Wenden, 1991). Moreover, Van Hest (2000) asserted that the ability to monitor one's L2 errors is a strong predictor of acquisition. Kormos (1999) also shows that the self-monitoring of L2 learning not only enhances acquisition, but also is a positive correlate of proficiency.

In essence, the findings of this study have some implications for EFL teachers, educators and administrators to establish successful paths for developing programs and activities that foster inference-making and deduction skills as well as self-monitoring among EFL students. Teachers, in particular EFL teachers, are suggested to develop and employ critical thinking abilities in the context of their classroom by assigning highly controversial topics for witting, encouraging thinking, reinforcing inference-making, using problem-based learning, providing feedback, etc. Additionally, self-regulation can be organized by active participation in environments requiring taking control of students' own learning process by themselves (Zimmerman, 2000).

\section{References}

Ackerman, J. M. (1993). The promise of writing to learn. Written communication, 10(3), 334-370. http://dx.doi.org/10.1177/0741088393010003002

Bailin, S., Case, R., Coombs, J. R., \& Daniels, L. B. (1999). Common misconceptions of critical thinking. Journal of Curriculum Studies, 31(3), 269-283. http://dx.doi.org/10.1080/002202799183124

Barnett, M. A. (1989). More than meets the eye. Foreign language reading: Theory and practice. Englewood Cliffs, NJ: Prentice Hall Regents.

Bean, J. C., \& Weimer, M. (2011). Engaging ideas: The professor's guide to integrating writing, critical thinking, 
Effect of inference-making, deduction, \& self-monitoring on language achievement, reading, \& writing ability and active learning in the classroom: Wiley.

Bereiter, C., \& Scardamalia, M. (1987). The psychology of written composition. Hillsdale, NJ: Lawrence Erlbaum Associates.

Blanche, P., \& Merino, B.J. (1989). Self-assessment of foreign-language skills: Implications for teachers and researchers. Language Learning, 39(3), 313-338. http://dx.doi.org/10.1111/j.1467-1770.1989.tb00595.x

Block, C. C., Gambrell, L. B., \& Pressley, M. (2002). Improving comprehension instruction: rethinking research, theory, and classroom practice: Jossey-Bass.

Bloom, B. S. (1956). Taxonomy of educational objectives: The classification of education goals. Cognitive Domain. Handbook 1: Longman.

Brown, H. D. (2001). Teaching by principles: An interactive approach to language pedagogy: Longman.

Cain, K., \& Oakhill, J. V. (1999). Inference making ability and its relation to comprehension failure in young children. Reading and Writing, 11(5-6), 489-503. http://dx.doi.org/10.1023/A:1008084120205

Cresswell, A. (2000). Self-monitoring in student writing: Developing learner responsibility. ELT journal, 54(3), 235-244. http://dx.doi.org/10.1093/elt/54.3.235

Davidson, B. W. (1998). Comments on Dwight Atkinson's "A critical approach to critical thinking in TESOL": A case for critical thinking in the English language classroom. TESOL Quarterly, 32(1), 119-123. http://dx.doi.org/10.2307/3587906

Durkin, D. (1993). What classroom observations reveal about reading comprehension instruction. Reading Research Quarterly, 14(4), 481-533. http://dx.doi.org/10.1598/RRQ.14.4.2

Ee, J., Moore, P. J., \& Atputhasamy, L. (2003). High-achieving Students: their motivational goals, self-regulation and achievement and relationships to their teachers' goals and strategy-based instruction. High Ability Studies, 14(1), 23-39. http://dx.doi.org/10.1080/13598130304094

Facione, N. C, \& Facione, P. A. (1996). Externalizing the critical thinking in knowledge development and clinical judgment. Nursing Outlook, 44(3), 129-136. http://dx.doi.org/10.1016/S0029-6554(06)80005-9

Facione, N. C., \& Facione, P. A. (1997). Critical thinking assessment in nursing education programs: An aggregate data analysis. California Academic Press.

Facione, P. A., Facione, N. C., Blohm, S. W., \& Giancarlo, C. A. F. (1990). The California critical thinking skills test manual: San Diego, CA: California Academic Press.

Facione, P. A. (1992). Critical thinking: What it is and why it counts. Retrieved from http://www.insightassessment.com/pdf_files/what\&why2006.pdf

Fahim, M., Bagherkazemi, M., \& Alemi, M. (2010). The relationship between test takers ${ }^{\text {ee }}$ critical thinking ability and their performance on the reading section of TOEFL. Journal of Language Teaching and Research, 1(6), 830-837. http://dx.doi.org/10.4304/jltr.1.6.830-837

Frijters, S., Ten Dam, G., \& Rijlaarsdam, G. (2008). Effects of dialogic learning on value-loaded critical thinking. Learning and Instruction, 18(1), 66-82. http://dx.doi.org/10.1016/j.learninstruc.2006.11.001

Gabennesch, H. (2006). Critical thinking: What is it good for? (in fact, what is it?). Skeptical Inquirer, 30(2), 36-41.

Ghanizadeh, A., \& Ghonsooly, B. (2014). A tripartite model of EFL teachers' attributions, burnout, and self-regulation: Towards the prospects of effective teaching. Educational Research for Policy and Practice, 13(2), 145-166. http://dx.doi.org/10.1007/s10671-013-9155-3

Ghanizadeh, A., \& Mirzaee, S. (2012). EFL Learners' self-regulation, critical thinking and language achievement. International Journal of Linguistics, 4(3), 451-468. http://dx.doi.org/10.5296/ijl.v4i3.1979

Ghanizadeh, A., \& Moafian, M. (2011). Critical thinking and emotional intelligence: Investigating possible relationships among EFL learners and the contribution of age and gender. Iranian Journal of Applied Linguistics, 14(1), 25-50.

Grabe, W. (1991). Current developments in second language reading research. TESOL quarterly, 25(3), 375-406. http://dx.doi.org/10.2307/3586977

Graham, S., \& Harris, K. R. (1993). Self-regulated strategy development: Helping students with learning problems develop as writers. The Elementary School Journal, 94(1), 169-181.

http://dx.doi.org/10.1086/461758 
Bagheri, F., \& Ghanizadeh, A.

Graham, S., \& R. Harris, K. (2000). The role of self-regulation and transcription skills in writing and writing development. Educational psychologist, 35(1), 3-12. http://dx.doi.org/10.1207/S15326985EP3501_2

Hacker, D. J. (1994). Comprehension monitoring as a writing process. Advances in Cognition and Educational Practice, 6, 143-172.

Harris, T. L., \& Hodges, R. E. (1995). The literacy dictionary: The vocabulary of reading and writing: International Reading Association.

Harter, S. (1996).Teacher and classmates influences on scholastic motivation, self-esteem, and level of voice in adolescents. In J. Juvonen \& K. Wentzel (Eds.), Social motivation: Understanding children's school adjustment (pp. 11-42). New York: Cambridge University Press. http://dx.doi.org/10.1017/CBO9780511571190.004

Harvey, S., \& Goudvis, A. (2000). Strategies that work: Teaching comprehension to enhance understanding. Stenhouse Publishers.

Hayes, J. R., \& Flower, L. S. (1980). Identifying the organization of writing processes. In L. W. Gregg \& E. R. Steinberg (Eds.), Cognitive Processes in writing (pp. 3-30). Mahwah, New Jersey: Lawrence Erlbaum Associates.

Heikkilä, A., \& Lonka, K. (2006). Studying in higher education: Students' approaches to learning, self-regulation, and cognitive strategies. Studies in Higher Education, 31(1), 99-117. http://dx.doi.org/10.1080/03075070500392433

Holliday, W. G., Yore, L. D., \& Alvermann, D. E. (1994). The reading-science learning-writing connection: Breakthroughs, barriers, and promises. Journal of research in Science Teaching, 31(9), 877-893. http://dx.doi.org/10.1002/tea.3660310905

Kamali, Z., \& Fahim, M. (2011). The relationship between critical thinking ability of Iranian EFL learners and their resilience level facing unfamiliar vocabulary items in reading. Journal of Language Teaching and Research, 2(1), 104-111. http://dx.doi.org/10.4304/jltr.2.1.104-111

Kealey, B. T., Holland, J., \& Watson, M. (2005). Preliminary evidence on the association between critical thinking and performance in principles of accounting. Issues in Accounting Education, 20(1), 33-49. http://dx.doi.org/10.2308/iace.2005.20.1.33

Kormos, J. (1999). Monitoring and self-repair in L2. Language learning, 49(2), 303-342. http://dx.doi.org/10.1111/0023-8333.00090

Langer, J. A., \& Applebee, A. N. (1987). How writing shapes thinking: A study of teaching and learning. NCTE Research Report No. 22: ERIC.

Lee, S. K. F., \& Loughran, J. (2000). Facilitating pre-service teachers' reflection through a school-based teaching programme. Reflective Practice, 1(1), 69-89. http://dx.doi.org/10.1080/713693131

Liaw, M. (2007). Content-based reading and writing for critical thinking skills in an EFL context. English Teaching and Learning, 31(2), 45-87.

Long, D. L., Oppy, B. J., \& Seely, M. R. (1997). Individual differences in readers' sentence-and text-level representations. Journal of Memory and Language, 36(1), 129-145. http://dx.doi.org/10.1006/jmla.1996.2485

Markman, E. M. (1979). Realizing that you don't understand: Elementary school children's awareness of inconsistencies. Child development, 50, 643-655. http://dx.doi.org/10.2307/1128929

McMahon, M., \& Dunbar, A. M. U. (2003). Facilitating reading comprehension through on-line collaborative annotation. Paper presented at the Apple University Consortium Conference.

Miller, S. L. (1981). The impact of a program of critical thinking on reading comprehension remediation and critical thinking of middle and high school students. Unpublished Doctoral dissertation. United States International University.

Mohammadyari, A. (2002). The relationship between critical thinking and change management of the heads of the educational departments in Ferdowsi University of Mashhad. Unpublished Masteral thesis, Ferdowsi University, Mashhad, Iran.

Moon, J. A. (2008). Critical thinking: An exploration of theory and practice: Routledge.

Moore, R. A. (1995). The relationship between critical thinking, global English Language proficiency, writing, 
Effect of inference-making, deduction, \& self-monitoring on language achievement, reading, \& writing ability

and academic development for 60 Malaysian second language learners. Indiana University.

MonshiToussi, M., Boori. A., \& Ghanizadeh. A. (2011).The role of EFL teachers' self- regulation in effective teaching. World Journal of Education, 1(2), 39-48.

Nash-Ditzel, S. (2010). Metacognitive reading strategies can improve self-regulation. Journal of College Reading and Learning, 40(2), 45-63. http://dx.doi.org/10.1080/10790195.2010.10850330

Nasirahmadi, A. (2014). The relationship between Iranian language learners' critical thinking ability and their reading comprehension achievement. International Journal of Research Studies in Language Learning, 3(7), 15-27. http://dx.doi.org/10.5861/ijrsll.2014.689

Norris, S. P., \& Ennis, R. H. (1989). Evaluating critical thinking. Pacific Grove, CA: Midwest Publications.

O'malley, J. M., \& Chamot, A. U. (1990). Learning strategies in second language acquisition. Cambridge University Press. http://dx.doi.org/10.1017/cbo9781139524490

O'Neil, H., Herl, H., Chung, G., Bianchi, C., Wang, S. 1., \& Mayer. C. (1999). Final report for validation of problem-solving measures. Los Angeles, CA: Center for the study of evaluation.

Oakhill, J. (1982). Constructive processes in skilled and less skilled comprehenders' memory for sentences. British Journal of Psychology, 73(1), 13-20. http://dx.doi.org/10.1111/j.2044-8295.1982.tb01785.x

Oakhill, J. (1984). Inferential and memory skills in children's comprehension of stories. British Journal of Educational Psychology, 54(1), 31-39. http://dx.doi.org/10.1111/j.2044-8279.1984.tb00842.x

ONeil, H. F., \& Herl, H. E. (1998). Reliability and validity of a trait measure of self regulation. Presented at the annual meeting of the American Educational Research Association. San Diego, CA.

Ormrod, J. E. (2006). Educational psychology: Developing learners. Pearson/Merrill Prentice Hall.

Paul, R. (2004). The state of critical thinking today: The need for a substantive concept of critical thinking. Retrieved from http://www.criticalthinking.org

Paul, R., Willsen, J., Binker, A. J. A., \& Thinking, Foundation for Critical. (1995). Critical thinking: How to prepare students for a rapidly changing world. Foundation for Critical Thinking.

Pecorari, D. (2006). Visible and occluded citation features in postgraduate second-language writing. English for Specific Purposes, 25(1), 4-29. http://dx.doi.org/10.1016/j.esp.2005.04.004

Phan, H. P. (2010). Critical thinking as a self-regulatory process component in teaching and learning. Psicothema, 22(2), 284-292.

Pithers, R. T., \& Soden, R. (2000). Critical thinking in education: A review. Educational Research, 42(3), 237-249. http://dx.doi.org/10.1080/001318800440579

Pratontep, C., \& Chinwonno, A. (2008). Self-regulated learning by Thai university students in an EFL extensive reading program. Journal of Humanities, 11(2), 104-124.

Quitadamo, I. J, \& Kurtz, M. J. (2007). Learning to improve: using writing to increase critical thinking performance in general education biology. CBE-Life Sciences Education, 6(2), 140-154. http://dx.doi.org/10.1187/cbe.06-11-0203

Renner, C. E. (1996). Enrich learners' language production through content-based instruction. Paper presented at the a National Conference on Lingua e Nuova Didattica, Modena, Italy.(ERIC Document Reproduction Service No. ED 411 694).

Rigg, P. (1991). Whole language in TESOL. Tesol Quarterly, 25(3), 521-542. http://dx.doi.org/10.2307/3586982

Rivard, L. P. (1994). A review of writing to learn in science: Implications for practice and research. Journal of Research in Science Teaching, 31(9), 969-983. http://dx.doi.org/10.1002/tea.3660310910

Schunk, D. H. (2005). Commentary on self-regulation in school contexts. Learning and Instruction, 15(2), 173-177. http://dx.doi.org/10.1016/j.learninstruc.2005.04.013

Schunk, D. H., \& Pajares, F. (2001). The development of self-efficacy. In A. Wigfield \& J. Eccles (Eds.), Development of achievement motivation (pp. 16-31). San Diego: Academic Press.

Sh, Jodeiri. (2005). The relationship between the critical thinking ability and writing proficiency of intermediate Iranian EFL student. Unpublished Masteral thesis Islamic Azad University, North Tehran Branch, Iran.

Shin, S. R. (2002). The effects of a metacognitive art criticism teaching strategy that incorporates computer technology on critical thinking skill and art critiquing ability. Doctoral dissertation, The Florida State University, Florida, US. 
Bagheri, F., \& Ghanizadeh, A.

Stapleton, P. (2001). Assessing critical thinking in the writing of Japanese university students insights about assumptions and content familiarity. Written Communication, 18(4), 506-548. http://dx.doi.org/10.1177/0741088301018004004

Swalander, L., \& Taube, K. (2007). Influences of family based prerequisites, reading attitude, and self-regulation on reading ability. Contemporary Educational Psychology, 32(2), 206-230. http://dx.doi.org/10.1016/j.cedpsych.2006.01.002

Tovani, C. (2000). I read it, but I don't get it: Comprehension strategies for adolescent readers. Stenhouse Publishers.

van Hest, E. (2000). Analyzing self-repair: An alternative way of language assessment. In G. Ekbatani \& H. Pearson (Eds.), Learner-directed assessment in ESL (pp. 75-88), New Jersey: Lawrence Erlbaum Publication.

Watson, G., Glaser, E., \& Corporation, Psychological. (2002). Watson-Glaser Critical Thinking Appraisal, UK Edition: Practice Test: Psychological Corporation.

Wenden, A. (1991). Learner strategies for learner autonomy. New York: Prentice Hall.

Winne, P. H., \& Hadwin, A. F. (1998). Studying as self-regulated learning. Metacognition in educational theory and practice, 93, 27-30.

Wolters, C. A., Pintrich, P. R., \& Karabenick, S. A. (2003). Assessing academic self-regulated learning. Paper presented at the conference on indicators of positive development. National Institutes of Health, Washington, DC.

Xiang, W. (2004). Encouraging self-monitoring in writing by Chinese students. ELT Journal, 58(3), 238-246. http://dx.doi.org/10.1093/elt/58.3.238

Zimmerman, B. J. (1990). Self-regulated learning and academic achievement: An overview. Educational psychologist, 25(1), 3-17. http://dx.doi.org/10.1207/s15326985ep2501_2

Zimmerman, B. J. (2000). Attaining self-regulation: A social cognitive perspective. In M. Boekaerts, P.R. Pintrich, \& M. Zeidner (Eds.), Handbook of self-regulation (pp. 13-39). San Diego, CA: Academic Press. http://dx.doi.org/10.1016/B978-012109890-2/50031-7

Zimmerman, B. J., \& Kitsantas, A. (1999). Acquiring writing revision skill: Shifting from process to outcome self-regulatory goals. Journal of educational Psychology, 91(2), 241-250. http://dx.doi.org/10.1037/0022-0663.91.2.241

Zimmerman, B. J., \& Pons, M. M. (1986). Development of a structured interview for assessing student use of self-regulated learning strategies. American Educational Research Journal, 23(4), 614-628. http://dx.doi.org/10.3102/00028312023004614

Zimmerman, B. J., \& Risemberg, R. (1997). Becoming a self-regulated writer: A social cognitive perspective. Contemporary Educational Psychology, 22(1), 73-101. http://dx.doi.org/10.1006/ceps.1997.0919

Zimmerman, B. J., \& Schunk, D. (2001). Reflections on theories of self-regulated learning and academic achievement. In B. Zimmerman \& D. Schunk (Eds.), Self-regulated learning and academic achievement: Theoretical perspectives ( $2^{\text {nd }}$ ed., pp. 289-307). Mahwah, NJ: Erlbaum. 